\title{
Forms and Trends of Encroachments in Cross River National Park of Nigeria
}

\author{
Henry Mmaduabuchi Ijeomah ${ }^{1}$, Edem Archibong Eniang ${ }^{2}$, Shafiu Kilishi Halidu ${ }^{3}$ \& Albert Nathan Onyejekwe ${ }^{1}$ \\ ${ }^{1}$ Department of Forestry and Wildlife, University of Uyo, P. M. B. 1017, Uyo, Akwa Ibom State, Nigeria \\ ${ }^{2}$ Department of Forestry and Wildlife Management, University of Port Harcourt, P.M.B. 5323 Port Harcourt, \\ Rivers State, Nigeria \\ ${ }^{3}$ Federal College of Wildlife Management, New Busa, Niger State, Nigeria \\ Correspondence: Henry Mmaduabuchi Ijeomah, Department of Forestry and Wildlife Management, University of \\ Port Harcourt, P.M.B. 5323 Port Harcourt, Rivers State, Nigeria. E-mail: henryijeomah@yahoo.com; \\ henry.ijeomah@uniport.edu.ng
}

Received: June 11, 2015 Accepted: June 17, 2015 Online Published: June 30, 2015

doi:10.5539/ijb.v7n3p103 URL: http://dx.doi.org/10.5539/ijb.v7n3p103

\begin{abstract}
Forms and trends of encroachments were investigated in Cross River National Park (CRNP) of Nigeria with the view of ascertaining the prevailing forms, trends, strategies of poaching and ecological consequences of illegal exploitations on the state of species in the biodiversity hotspot; that is contiguous with Korup and Takamanda national parks of Cameroon. Data for this study were obtained through personal observations, administrative record, structured questionnaires and in depth interview with experienced members of park protection staff who have been in the park for a minimum period of five years and are therefore quite knowledgeable about wildlife management and protection in the park. A set of questionnaire was randomly administered to 40 Park protection staff of CRNP in other to examine the forms, trends, intensity and reasons for encroachment in the park. Data on trend of arrest being an indicator of encroachment was collected from the administrative record of CRNP. Data obtained were analyzed using descriptive statistics in form of percentages and frequency of counts. Hunting $(100 \%)$ and collection of Non Timber Forest Products (NTFPs) (75\%) were implicated as the highest form of encroachment in the park while fuel wood collection (15\%) was the least. The highest and lowest forms of arrest between 1991 and 2014 were $12.8 \%$ and $0.2 \%$ respectively. The least annual arrest $(0.2 \%)$ recorded between 1991 and 2014 was in 1994 and 1995 respectively. Out of 616 arrests made between 1991 and 2014 34.\%, 28.9\% and $26.1 \%$ were for logging, hunting and collection of NTFPs respectively while aiding and abetting had the least record of only $1.6 \%$. Nevertheless most respondents implicated households of host and enclave communities as encroachers $(85.00 \%)$ and aiders of encroachments $(95.0 \%)$ in CRNP. Cross River National Park is porous to non-seasonal encroachment as the anti poaching operations therein are ineffective.
\end{abstract}

Keywords: Encroachment, Wildlife, Biodiversity Conservation, Non timber Forest Products, Cross River National Park, Nigeria

\section{Introduction}

Biodiversity is globally faced with serious challenges of habitat destruction and over exploitation due to tremendous increase in human population and its consequential rise in development and demand for food especially animal protein that is hardly available at affordable prices for poor rural inhabitants. In other to check over exploitation of biodiversity and extinction of species, protected areas such as strict nature reserve, national parks, game reserves, wildlife sanctuaries and forest reserves were created for preservation of ecosystems, conducting scientific researches for conservation of species, and recreational aspect of wildlife termed ecotourism.

Nigeria has seven national parks with Cross River National Park (CRNP) being the riches in diversity among the three in southern part of Nigeria. The CRNP alone has 56 species of snake, the highest in the whole of Niger Delta (Eniang \& Ijeomah, 2011a). It is rich in endemic species and has varied ecosystems. CRNP is the representation of the Cross River rainforest - the only tropical rainforest left unaltered in Nigeria. It ranks among the largest contiguous rainforest left in Africa (Anon, 1996 as cited by Edet \& Akinyemi, 2010). The rainforest of Cross River is one of the 
richest in species diversity and endemism in the world, and it is a home to over 700 species of plants and animals; and according to Cross River State Forestry Project (CRSFP) (1994) over 430 of these species are used by local residents.

Park managements were employed with the responsibility of preventing exploitation of forest and wildlife resources, and allowing only limited access to protected areas. However, Ijeomah (2012) maintains that only national parks and few game reserves give consideration to management of wildlife in Nigeria. Even inside most national parks, game reserves and wildlife sanctuaries created purposely for protection of species, game populations and their microhabitats still appear to be under serious threat as a result of various forms of encroachments. There is no protected area in the world where encroachment is not experienced, though the form and rate differs.

In the case of Nigeria every game species including those abundant in national parks are under pronounced threats of either hunting or habitat destruction. Ijeomah and Emelue (2009) reported that many herds of elephant at Kainji Lake National Park have on several occasions emigrated to Niger Republic due to poaching threats. The lurking of insurgents in Sambisa Game Reserve in Borno State of Nigeria for several months is among the extreme forms of encroachment experienced in protected areas. The insurgents overpowered the management of Sambisa Game Reserve, exterminated most visible animal species in the refuge, over exploited several non-timber forest products, hampered tourism and reduced the parks' ecological status below that of a forest reserve- annual migration of animals from Cameroon through wildlife corridors to the reserve were halted as many immigrants were poached and the environment altered (Ijeomah et al., 2014).

Though protected areas have many similar forms of encroachment challenges every national park or game reserve has site - specific form of encroachment threat. As a result of communal crisis Wase Wildlife Park has been permanently destroyed (Ijeomah et al., 2005). Due to encroachment pressure for farming one third of the Pai River Game Reserve of Plateau State was de-reserved, while the remaining two third became finally inhabited by armed herdsmen (for over a decade), who consistently attack inhabitants of the area especially on market days ((Ijeomah, 2007; Ijeomah, 2012; Ijeomah et al., 2014). Hoodlums once invaded uncompleted and abandoned buildings in Rayfield resort, an ecodestination in Plateau State, and seized, roasted and consumed goats belonging to households in the host communities (Ijeomah, 2007; Ijeomah et al., 2014). Hoodlumps have encroached into many forest reserves in western Nigeria, especially in Ondo State; where they cultivated hectares of Indian hemp (Ijeomah et al., 2014) sometimes in connivance with forest guards. Political instability in many parts of the world has created more opportunities for encroachment of terrorists into conserved areas especially in parks located within state or national boundaries. Ecodestinations in Kenya have become major hiding areas for terrorists and targets for attacks by terrorists (This Day in History, 1998; Filkings, 2002; Raman, 2002; Gettleman \& Kulish, 2013; Misiko, 2014).

With CRNP being located very close to Cameroon, having about 430 of species therein utilized by households from host communities, and being established in an agrarian state where the major source of inhabitants' survival depends on agriculture and resources from the forest, the park is very prone to encroachment. However, the forms and trends of encroachment, reasons and strategies for encroachment and the ecological consequences of poaching therein are yet to be ascertained. For effective protection of the vast and unique resources of Cross River National Park, it therefore becomes imperative to investigate the specific forms and trends of encroachment prevalent in the park. This study therefore evaluates different forms and trend of encroachment experienced in Cross River National Park, and investigates the prevailing strategies of encroachment and its ecological consequences on the state of biodiversity in the park.

\section{Methodology}

\subsection{Study Area}

The study area, Cross River National Park (CRNP) lies between latitude $5^{\circ} 05^{\prime}$ and $6^{\circ} 29^{\prime} \mathrm{N}$ and longitude $8^{\circ} 15^{\prime}$ and $9^{\circ} 30^{\prime} \mathrm{E}$ in the South eastern part of Nigeria in Cross River State. The park was established by Decree No. 46 of 1991 (now Act No. 46 of 1991) in the Laws of the Federal Republic of Nigeria as amended in 1999. The Park covers a total area of $4000 \mathrm{~km} 2$ and segmented into two non-contiguous Divisions - the Oban hills in the Southern part of the Park, which covers $3000 \mathrm{~km}^{2}$ and the Okwangwo Division in the Northern part of the park that covers $1000 \mathrm{~km}^{2}$. The park has a tropical climate characterized by a rainy season between April and November. Cross River National Park (CRNP) is one of the richest areas of tropical rainforest in West Africa, it contains one of the last remaining rainforests in Nigeria (Ite, 2004).

\subsection{Method of Data Collection}

Data for the study were collected through administration of a set of structured questionnaire to park officials. Also, information were collected through observation and interview of experienced officials of the park, students who 
were on industrial attachment and households who are quite knowledgeable about encroachments in CRNP. Data on arrest of poachers were collected from administrative records of CRNP.

The set of questionnaire was randomly administered to 40 park protection staff of CRNP Park.

\subsection{Method of Data Analysis}

The data obtained from the study area were analysed using descriptive statistics in the form of frequencies of count and percentages.

\section{Results}

\subsection{Different Forms of Encroachment}

Results on the different forms of encroachment in CRNP are presented in Tables 1 and 2.

Table 1 shows that the highest form of encroachment in CRNP is hunting (100\%), followed by fishing and collection of NTFPs $(75 \%)$ while the least was collection of fuel wood $(15 \%)$.

Table 1. Forms of encroachment experienced in Cross River National Park (CRNP) as indicated by Staff respondents

\begin{tabular}{cccc}
\hline S/N & Forms of Encroachment & Frequency & Percentages\% \\
\hline 1 & Hunting & 40 & 100.0 \\
2 & Collection of NTFP & 30 & 75.0 \\
3 & Fishing & 28 & 70.0 \\
4 & Farming & 18 & 45.0 \\
5 & Wood for timber(logging) & 10 & 25.0 \\
6 & Fuel wood & 6 & 15.0 \\
\hline
\end{tabular}

According to Table 2 animals (100\%) and Non Timber Forest products (100\%) top the list of items collected through encroachment in CRNP. This is followed by fish (45.0\%) and wood for timber (25.0\%).

Table 2. Items collected through encroachment in CRNP

\begin{tabular}{ccc}
\hline & Frequency & Percentage (\%) \\
\hline Animals & 40 & 100.0 \\
NTFP & 40 & 100.0 \\
Fish & 18 & 45.0 \\
Wood for timber & 10 & 25.0 \\
\hline
\end{tabular}

\subsection{Trend of Encroachment}

Table 3 shows the highest and lowest form of arrest between 1991 and 2014 as $12.8 \%$ and $0.2 \%$ respectively. The number of arrest in $1994(0.2 \%)$ and $1995(0.2 \%)$ were the least.

Table 4 shows that $85.0 \%$ of the respondents admitted that encroachment is experienced in CRNP. Majority of the respondents suspect indigenes of host communities as encroachers $(80.0 \%)$ and aiders of encroachment $(95.0 \%)$ in the park.

\subsection{Seasons of Intense Encroachment}

Table 5 shows that rainy season (37.0\%), was indicated as the highest season of intense encroachment in CRNP. Encroachers perceive that bad road network and difficult terrain $(45.0 \%)$ of the park could hinder park officials from having easy access to various areas to arrest encroachers. The abundance of flora and fauna $(35.0 \%)$ during rainy season serves as an irresistible temptation to many encroachers. Only few respondents $(5.0 \%)$ indicated that scarcity of flora and fauna during dry season attracts intense encroachments. Nevertheless $35.0 \%$ of the respondents admitted that intense encroachment can take place at all seasons of the year. 
Table 3. Number of culprits arrested for different forms of encroachment in CRNP between 1991 and 2014

\begin{tabular}{|c|c|c|c|c|c|c|c|c|c|}
\hline $\mathrm{S} / \mathrm{N}$ & Years & Logging & Hunting & Farming & Aiding \& Abetting & NTFPs & Water poisoning & Annual Total & $\begin{array}{c}\text { Percentage of } \\
\text { total encroachments }\end{array}$ \\
\hline 1 & 1991 & 0 & 0 & 0 & 0 & 0 & 0 & 0 & 0 \\
\hline 2 & 1992 & 0 & 0 & 0 & 0 & 0 & 0 & 0 & 0 \\
\hline 3 & 1993 & 0 & 0 & 0 & 0 & 0 & 0 & 0 & 0 \\
\hline 4 & 1994 & 0 & $1(0.6)$ & 0 & 0 & 0 & 0 & 1 & 0.2 \\
\hline 5 & 1995 & 0 & $1(0.6)$ & 0 & 0 & 0 & 0 & 1 & 0.2 \\
\hline 6 & 1996 & 0 & 0 & 0 & 0 & 0 & 0 & 0 & 0 \\
\hline 7 & 1997 & $10(4.7)$ & $3(1.7)$ & 0 & 0 & $3(1.9)$ & 0 & 16 & 2.6 \\
\hline 8 & 1998 & 0 & 0 & 0 & 0 & 0 & 0 & 0 & 0 \\
\hline 9 & 1999 & 0 & $1(0.6)$ & 0 & 0 & 0 & 0 & 1 & 0.2 \\
\hline 10 & 2000 & $13(6.1)$ & 0 & 0 & 0 & $2(1.2)$ & 0 & 15 & 2.5 \\
\hline 11 & 2001 & $7(3.3)$ & 0 & 0 & 0 & 0 & 0 & 7 & 1.5 \\
\hline 12 & 2002 & $8(3.8)$ & $10(5.6)$ & 0 & $2(20.0)$ & $6(3.7)$ & 0 & 26 & 4.2 \\
\hline 13 & 2003 & $6(2.8)$ & $6(3.4)$ & $1(2.9)$ & 0 & $28(17.4)$ & 0 & 41 & 6.7 \\
\hline 14 & 2004 & $11(5.2)$ & $20(11.2)$ & $7(20.6)$ & $3(30.0)$ & $6(3.7)$ & 0 & 47 & 7.6 \\
\hline 15 & 2005 & $39(18.4)$ & $18(10.1)$ & 0 & 0 & $6(3.7)$ & 0 & 63 & 10.2 \\
\hline 16 & 2006 & $11(5.2)$ & $6(3.4)$ & 0 & 0 & $1(0.6)$ & 0 & 18 & 2.9 \\
\hline 17 & 2007 & $14(6.6)$ & $10(5.6)$ & 0 & 0 & $4(2.5)$ & 0 & 28 & 4.6 \\
\hline 18 & 2008 & $32(15.1)$ & $18(10.1)$ & 0 & $1(10.0)$ & $28(17.4)$ & 0 & 79 & 12.8 \\
\hline 19 & 2009 & $7(3.3)$ & $12(6.7)$ & 0 & $1(10.0)$ & $6(3.7)$ & $10(47.6)$ & 36 & 5.8 \\
\hline 20 & 2010 & $10(4.7)$ & $20(11.2)$ & 0 & 0 & $6(3.7)$ & $7(33.3)$ & 43 & 6.9 \\
\hline 21 & 2011 & $23(10.9)$ & $14(7.9)$ & $18(52.9)$ & $3(30.0)$ & $16(9.9)$ & $1(4.8)$ & 75 & 12.1 \\
\hline 22 & 2012 & $15(7.1)$ & $21(11.7)$ & $5(14.7)$ & 0 & $21(13.0)$ & & 62 & 10.1 \\
\hline 23 & 2013 & $6(2.8)$ & $17(9.6)$ & $3(8.9)$ & 0 & $28(17.4)$ & $3(14.2)$ & 57 & 9.3 \\
\hline \multicolumn{2}{|c|}{ Form Total } & 212 & 178 & 34 & 10 & 161 & 21 & 616 & \\
\hline \multicolumn{2}{|c|}{ Form percentage } & 34.4 & 28.9 & 5.5 & 1.6 & 26.1 & 3.4 & 100 & \\
\hline
\end{tabular}

Table 4. Perception of staff respondents concerning encroachment in CRNP

\begin{tabular}{|c|c|c|c|c|}
\hline $\mathrm{S} / \mathrm{N}$ & Perception on encroachment & Variables & Frequency & Percentage $\%$ \\
\hline \multirow{2}{*}{1} & \multirow{2}{*}{ Is encroachment experienced in CRNP? } & Yes & 34 & 85.0 \\
\hline & & No & 6 & 15.0 \\
\hline \multirow{2}{*}{2} & \multirow{2}{*}{ Who are the encroachers? } & Indigenes & 32 & 80.0 \\
\hline & & Non-indigenes & 8 & 20.0 \\
\hline \multirow{2}{*}{3} & \multirow{2}{*}{ If community aid encroachers in anyway } & Yes & 38 & 95.0 \\
\hline & & No & 2 & 5.0 \\
\hline
\end{tabular}

Table 5. Seasons of intense encroachment in CRNP

\begin{tabular}{ccc}
\hline Seasons & Frequency & Percentage $\%$ \\
\hline Rainy season & 15 & 37.5 \\
Dry season & 2 & 5.0 \\
Festival & 0 & 0.0 \\
All season & 23 & 35.0
\end{tabular}

Reason for answer

Bad road network $\quad 18 \quad 45.0$

Abundance of flora \& fauna $\quad 14 \quad 35.0$

Scarcity of flora \& fauna $\quad 2 \quad 5.0$




\section{Discussion}

\subsection{Forms of Encroachment}

Hunting was indicated by all respondents as a form of encroachment in CRNP (table 1). This implies that the level of awareness of hunting as a form of encroachment is very high among all park protection staff of CRNP (irrespective of the number of years they have worked with the park). It also implies that encroachment through hunting is rampant in the park. Common occurrence of hunting in the park can be attributed to the high rate of unemployment prevalent in the bordering communities. Unemployed males resort to hunting as a substitute to employment while unemployed females embark more on collection of NTFPs such as Gnetum africanum, Irvingia gabonensis and Irvingia wombolu for preparing various native delicacies. Some females also harvest and market non timber forest products harnessed freely from the wild or park. This is also the reason that made all respondents $(100 \%)$ listed collection of NTFPs as a major form of encroachment in the park (table 1). Nevertheless, NTFPs are not only harvested by females. NTFPs could be harvested by young and adult males and females depending on the species. This agrees with the report of Udofia et al. (2009).

Bushmeat harnessed through hunting can be sold to generate income and also serves as a source of the much needed animal protein in rural areas. Poachers can kill species irrespective of their IUCN conservation status. A lot of money is generated by selling animal species especially the endangered ones which are secretly marketed in many areas in Cross River State. Drills, Mona monkeys, Red columbus monkeys, Bush pigs, Duikers, Hyraxes and large rodents normally move in groups in the park and are therefore mostly targeted by poachers. Primates are the most killed with drills being extremely affected as the group is semi arboreal - the species spend a lot of time foraging in forest litter. More so the adoption of a cultural hunting strategy which uses specially trained dogs that sniff out wild animals (until the hunter gets to the scene) makes drills particularly vulnerable. The high demand for bushmeat instigates poachers to embark on illegal hunting as scarcity of the product increases the price of available ones. This agrees with the findings of Eniang and Ijeomah (2011b). It also agrees with the report of Onu and Ijeomah (2011) on bushmeat marketing in Omagwa. Encroachment in form of fishing was indicated by many respondents (Table 1).

Apart from hunting the only available source of harnessing animal protein at little or no cost in the study area and in a less noisy or noticeable manner is fishing. Fishing is mostly carried out by enclave communities using poisonous chemicals. Few respondents indicated logging. This cannot be unconnected with the fact that the operation is a noisy one and encroachers are mostly caught unlike hunting, fishing and collection of NTFPs which could be carried out unnoticed. The fear of being apprehended therefore discourages some potential encroachers from embarking on logging operation. Nevertheless, noise is not a total limitation to encroachment by logging because of the large size of the park and distances apart. Besides, encroachment by logging is always embarked upon on Sundays and public holidays when rangers are off duty. Similarly Eniang and Ijeomah (2011b) reported that endangered wildlife species are marketed at odd hours (when law enforcement officials are yet to resume duty) in bushmeat markets in Cross River State.

Encroachment by logging, though limited, is experienced especially near fast flowing rivers that could help poachers raft and float the logs far away from the park. Fuel wood (15\%) was the least indicated form of encroachment in CRNP. This can be ascribed to the fact that there are many alternative sources of fuel wood in the study area especially the farms. Besides, other sources of fuel such as kerosene are quite affordable to the masses. No culprit was arrested for grazing cows. This is because most households in the host communities are not cattle rearers unlike in Yankari Game Reserve and Kainji Lake National Park that are parks in savanna areas- grasslands where most households inhabiting the areas are nomads. Besides, the thickness of the forests in the park, as a typical rainforest environment, hardly allows penetration of light and therefore hinders growth of grasses unlike in savanna areas.

\subsection{Poaching of NTFPs in CRNP and its Ecological Consequencies}

The rate of poaching of NTFPs in the park is very high (table 1). Many NTFPs are regularly poached from the park most times in a manner that threatens the existence of the species and other biological resources in the environment. Some of the species always poached from CRNPs are Carpolobia lutea (cattle stick or poor man's candle), Irvingia spp., Archachatina spp., Piper guinensis, Edible mushrooms of different species, Gnetum africanum, Garcinia manii, Cola acuminata, Kola edulis, African Walnut, Brachystegia spp - Achi(in Ibo): harvested extensively; Mimosops; Locust bean, Parkia biglobosa; Pentaclethra macrophylla is harvested but not as extensive as others. Other NTFPs harvested include Lasiethera africana-Editan (Ibibio) and Hensia crenataAtama (Ibibio). 
The trend of exploitation of Carpolobia lutea, a multipurpose species is very enormous. This high level of exploitation could be attributed to the fact that this species, cattle stick, is the preferred species for cattle stick among Fulani cattle rearers in West Africa, because of its high tensile strength. Cattle rearers perceive that Carpolobia lutea has a magical or spiritual strength which may bring about madness when used on man and therefore abhor using this species to whip humans (except in times of inter tribal wars).The high level of exploitation of this species from CRNP can also be ascribed to the fact that over the years many Fulani tradesmen discovered that the major source of cattle stick in West Africa is along the last remnant of the tropical rainforest which forms the Cross River National Park. Poachers of this species, Carpolobia lutea have at least three different strategies of exploiting this species.

One of such and the most ecologically disastrous is the community based system whereby a middle man from park host community liaises with chiefs in the community to give approvals for some Fulanis and tradesmen to enter the enclave community or support zone community whose community land shares boundary with the park. These Fulanis cum foreign tradesmen are then given access into the community forest to harvest at least a tractor load of cattle stick on agreed monetary terms which varies on basis of community. The plant normally harvested is an average Diameter at Breast Height (DBH) of $5.5 \mathrm{~cm}$. In essence the cumulative number of sticks eventually got from the park per poaching expedition depends on how many sticks an individual can get from a plant. A specially crafted pick axe or a specialized axe with two heads is used for harvesting the species by the tradesmen. One head of this harvesting implement serves as a pick axe which penetrates through the soil or rock surface efficiently while the opposite side (that is heavier and flattened like a knife) helps to excavate and cut through the tap root system of the plant. This harvesting method is adopted because through experience the tradesmen discovered that the tap root portion of the wood has a higher tensile strength that prevents the wood from splitting no matter how hard the stick is hit on cattle, unlike the rest of the wood which may split. This anti conservation harvesting strategy ensures that the plant does not regenerate any longer.

The tradesmen do not enter the forest with tractors as none is available for use whereas tractor loads need to be harvested. More so, there is no available means of estimating a tractor load to the tradesmen. The strategy adopted therefore becomes to harvest as many cattle sticks as possible that could be harvested by the available labour within the number of days that might be spent inside the forest. The tradesmen are neither accompanied by members of the community nor park officials and are therefore not supervised. This is worsened by the fact that Fulani tradesmen have no idea of park or community boundary. They keep on moving forward and harvesting as far as the species could be found whereas the bulk of the species is really in the park and not in the community forests. As the Fulani tradesmen continuously advance forward in search of the cattle stick, they enter Korup National Park and Takamanda National Park which are contiguous with CRNP. When the Fulani tradesmen feel that the quantity gathered can full the required number of tractors, they send message to the middleman in the community for provision of a tractor. A tractor carries between 3 to 5 tons of the cattle stick at once depending on the terrain of the park and season to Bokobiri (Hausa community in Calabar). During rainy season the tractor hardly carries many tons because of the difficult terrain in the forest. The tractor loads are heaped in the community where trailers from Northern parts of Nigeria especially Katsina, Kano, Gombe etc. carry the tons of cattle sticks. From these locations in Nigeria the cattle sticks are exported to the entire West African sub region where cattle are reared including Mali, Bokinafaso, Chad etc. This is done at all season.

When the trailer becomes full, the excess loads at the gantry are left in the forest to waste as nobody can go to such a far distance from the community into the forest or the national park to trace and carry the cattle sticks even for fuel wood. Sometimes the tradesmen miss their route in the forest due to the relatively large size of the area. Similarly, Ijeomah and Ogbara (2013) reported that rangers in Kainji Lake National Park sometimes miss their route inside the park and therefore use large and marked individuals of plants as indicators to trace their direction in the protected area. The quantity of cattle stick that can full eight tractors may be harvested by the tradesmen based on wrong calculation of what a trailer can carry, but the trailer may end up carrying only 5 tractor loads with the remaining three tractor loads wasted. This always happens because the harvesters have no idea of how many tractor loads that can full a trailer. Sometimes flood caused by heavy rain experienced after harvesting may discourage the tradesmen from carrying heaps of the cattle stick. i.e. the tractor may not be able to access the area because of the flood.

As harvesting of cattle stick is consistently embarked on, trails are created and the forest becomes opened by network of trails created by cattle stick tradesmen. This trails and camps created by tradesmen form openings for poachers and other NTFPs users. The tradesmen embark on continuous harvest without planting and through this means have endangered the species that is traditionally used for the treatment of various ailments (Burkill, 1985; Mitaine-offer et al., 2002; Nwidu and Nwafor, 2009; Okokon et al 2011; Bero et al., 2011; Jackson et al., 2011; 
Nwidu et al., 2011; Idowu et al., 2005; Ettebong and Nwafor, 2009; Ajiwhen and Bisong, 2013), including memory enhancement and madness. A typical stick is taken away from the forest at economic worth of $\$ 150.00$ (One hundred and fifty naira). If processed and dried at Bokobiri in Calabar (the Hausa community in Calabar) it worths between $\$ 380$ and $\$ 400.00$ (USD 2.00), but gets to Kano or Katsina at 700 - $\$ 750$. Recently because of police disturbances, the tradesmen prefer to carry the sticks unprocessed in order to avoid being arrested at police check points. Security personnel at check points are deceived that heaps of the species are fuel woods or sticks meant for building houses.

Proceeds from this anti conservation business of cattle stick never trickle down to community members but shared only by members of the cartel. Park officials are unaware of the huge economic importance of the species. The tradesmen have been difficult to stop because the park is penetrated through the community and done quietly without shooting guns.

For Irvingia species, the users enter inside CRNP and pack all the fallen fruits. Men, women and children are involved in this form of harvesting. Officials hardly check these encroachers. Regeneration of the species is limited by these collections because most of the fruits that fall on the ground are taken away. An Irvingia full of evaporated milk cup costs $\$ 400.00$ (USD 2.00), tomatoe cup costs $\$ 200.00$ (USD 1.00) but in scarce season it may increase. Collection of Irvingia species is usually carried out between May and September. By this harvesting the poachers upset the apes, elephant, birds and other animals that normally feed on fruits of the species.ie they affect the feeding and ranging behavioural ecology of other animals that depend on these fruits. Monkeys on siting these poachers scatter. Some of the men who enter the park to pick Irvingia fruits sometimes go with guns and hunting dogs as form of protection while in the forest. Many of these Irvingia seed collectors also set traps for animals and secretly kill wild animals. Presently, park officials disallow Irvingia collectors but the park is too large for the few rangers to monitor. Previously, park officials collect some Irvingia fruits from these encroachers, when caught, before finally releasing them. In the case of Gnetum africanum the collectors stay in the forest for about three days to accumulate a lot. Once Gnetum plant gets to the height that the collectors cannot climb the poachers fell the tree to harvest it. Even female collectors stay up to three days in the forest. The fresh leaves of Piper guinense are always up the tree because the leaves close to the ground may not be fresh due to regular harvest. In order to get the fresh part of the Piper guinense, the collectors fell the tree. The felling of these trees opens up the forest.

Encroachers harvest lorry loads of mushrooms, Lactarius deliciosus (the species that normally grows on stems of trees - Okokobioko (Ibibio). i.e hard tissue mushroom). This is very critical, children carry basins to load the mushrooms in lorries. Awareness of none poisonous woods to harvest mushrooms from, and poisonous species that should be avoided is very high among members of host communities. Encroachment to harvest mushroom allows collectors identify other essential edible wild vegetables and fruits which may attract them to attempt frequenting the park. Ability to resist the temptation of encroaching for those identified wild vegetables depends on individuals. Among other NTFPs heavily collected from CRNP are snails, Rattan cane, Rattan bamboo etc. Most cane and rattan bamboo used in many parts of Nigeria are sourced from CRNP. Biodiversity Preservation center, a non governmental organization is presently teaching households in Itam community of Akwa Ibom State how to plant Rattan cane to enable them later harvest from their farms instead of relying on poached ones from CRNP (Gideon, Personal communication).

The rate of harvesting Massularia acuminata is also high. It is harvested and sold to people who use it as a chewing stick. Many parts of Nigeria depend on Cross River axis for chewing stick, which are mainly sourced from the national park. These users believe that chewing stick made from Massularia acuminata and Garcinia manii are medicinal. They are preferred species for chewing stick. Brachystegia spp - Achi(in Ibo); Mimosops; African walnut, Tetracarpidium conophorum and Locust bean are harvested extensively while Pentaclethra macrophylla is harvested but not as extensive as others.

Kola edulis is extensively harvested as it is very expensive. Five of the species sell for a hundred naira. It is cherished but people hardly plant it. Harvesting of the stems of different plant species opens up the forest and creates trails for poachers and alters micro habitats of species, while the harvesting of wild vegetables and fruits affects the feeding pattern and behaviour of most animals that depend on these fruits for feeding.

\subsection{Trend of Encroachment}

Between 1991 and 1993 no arrest was made as encroachment was either very minimal or that the pressure of encroachment was not noticeable among the protection unit of the park. The minimal pressure could be attributed to the promises of employment, empowerment and provision of social facilities made to host communities by the management of CRNP. It could also mean that households from host communities were happy concerning the park - a federal government establishment that was newly sited in their community. Between 1994 and 1995 two 
hunters were caught. This shows that hunting is the major source of animal protein in the area. It also implies that households were gradually becoming tired of waiting endlessly without 'all the made promises' being fulfilled by the management of CRNP. Interactions and conflicts with the management concerning the arrest of the two culprits scared households from encroachments. Hence, there was no arrest in 1996 though there would have been encroachments. Households still expected that all the promises would soon be fulfilled.

In 1997, many households disregarded the unfulfilled promises, summoned courage and encroached into the park. The fact that a total of 16 culprits were arrested implies that some may have escaped. The fact that 10 culprits were arrested for logging, an operation that can be easily detected due to its noisy form shows that the culprits were determined, organized and ready to face opposition from park management. It could also imply that rangers became motivated and therefore embarked on anti poaching operations during public holidays. It was still in 1997 that the highest number of arrests was made in hunting and collection of Non timber forest products since inception of the park in 1991. This implies that many people may have been encroaching to collect NTFPs but were not arrested, as park officials in error paid no attention to such encroachments or may have been collecting some parts of the poached items from them as 'gate pass'. Also, this confirms that households were already tired of unfulfilled promises of CRNP and therefore wanted to embark on 'occult compensation'. This high level of encroachment in 1997 generated series of conflicts between host communities and park management, and because of the consequences of the conflicts plans for encroachments were not executed by many potential encroachers, thus encroachments reduced till the year 2000 when it became very pronounced and serious. The level of encroachment and strategies used in carrying out the operation scared CRNP management. Awareness campaigns on the need to protect park resources were therefore consistently made while the host communities were given more assurance on provision of most basic facilities by the management. This increased level of seriousness of encroachment and fear of losing vital biodiversity by CRNP management led to provision of more anti poaching facilities such as boats, field vehicles and guns to make park protection more effective. Parachute would have been introduced for monitoring but because of visibility challenges usually faced in Cross River National Park due to its tropical nature Parachutes are mostly used in parks located in savannah regions such as the Kainji Lake National Park and Yankari Game Reserve. Ijeomah et al (2013) reported the use of parachute in Kainji Lake National Park.

The motivation of staff through provision of anti poaching facilities resulted in apprehension of many encroachers between 2001 and 2013. However, trend of arrest is only an indication of trend of encroachment and does not mean that every form of encroachment or that all individuals involved in encroachment were arrested. It is basic that many encroachers resisted arrest, some escaped after being arrested, while some cannot be arrested because of how organized the group could be or the type of sophisticated weapons they possessed. The fact that $20.6 \%$ of arrests in 2004 encroached for farming is an indication that households in the host communities were no longer afraid of being arrested because farming cannot be secretly embarked upon - even when encroachers were not found the farm could be seized or destroyed. It is also an indication that the households were protesting and agitating to reclaim their lands used for national park if not given the desired compensation.

The highest number of culprits arrested was for logging operation (table 3). It is easier to apprehend those involved in logging than those involved in hunting of animals and collection of non-timber forest products. This is because, logging is noisy and easily noticeable operation. Also, it requires more than one person in most cases to embark on logging unlike hunting and collection of non timber forest products. Similarly, in Kainji Lake National Park of Nigeria, encroachment in the form of grazing was the most common but hunters were more arrested. The culprits involved in grazing were hardly apprehended as they always escape and leave their cows (which will be seized and later released) or sometimes encroachers use charms to turn to cow and can hardly be seen by park protection staff (Ijeomah et al., 2013). In the real sence the most common form of encroachments in CRNP are hunting and collection of non timber forest products (table 1). This shows that the survival of households in these communities depends highly on resources from the forest. Bushmeat is their major source of animal protein since it is harnessed at no financial cost. The condiments and herbs used for daily preparation of meals and medication respectively are also sourced from the non timber forest products.

The fact that $47.6 \%$ of culprits arrested in 2009 were involved in poisoning of water using chemical to harness fish shows that they were not only harvesting fish for consumption but ready to destroy the resources in the park. In essence the culprits wanted to harvest all the fishes at once. This agrees with NEST (1991) that the poor masses would always destroy the environment to survive. The use of chemical for catching fish also indicates that the catches were for sale and not for household consumption. No culprit was arrested for water poisoning from the period of inception in 1991 till 2009 being a period of about 18 years, and the first year to arrest offenders involved in this form of encroachment, 10 sets were arrested. This shows that either previous offenders have been escaping without being arrested or that park officials have been deliberately allowing them to harvest fish and escape. 
The highest numbers of arrests were made in 2008 and 2005 with values of 79 and 63 respectively (table 3 ). At this time the local communities have lost confidence in the management of CRNP. The youths of the communities in many cases threatened towards disregarding park management laws and were no longer interested in creating awareness towards conservation of park resources. The number of culprits arrested in CRNP is relatively smaller than that of Kainji Lake National Park where 372 culprits were arrested in 1999 and the least number of annual arrests were 67 and 70 (Ijeomah et al., 2013). This reveals the level of ineffectiveness of anti poaching operations in CRNP because several bushmeat markets in Calabar get daily supply of different species of wild animals from hunters who may be encroaching into CRNP (Eniang \& Ijeomah, 2011b).

This low number of arrests could be attributed to inadequate number of staff, non motivation of protection staff and visibility challenges. Oban range is about $3000 \mathrm{~km}$ and presently broken into two ranges; Oban west range and Oban east range for the purpose of management. The probability of about 150 rangers effectively monitoring such a large range with difficult terrain is hard. The fact that there are some enclave communities makes it more difficult for officials to manage. The CRNP fused together in some of its sector - Ikpan forest block with Korup National Park of Cameroon and Takamanda National Park of south west Cameroon. Korup National Park which is larger in size has lesser number of officials to guard the park. This large area therefore becomes a large hunting ground for Nigerian poachers who can walk up to thirty kilometres on foot to hunt. Korup National Park is therefore more accessible from the Nigerian side and more protected in Cameroon's side.

The low number of arrests can also be attributed to connivance of staff with offenders. The fact that out of 616 arrests made from inception of CRNP to 2014, aiding and abetting of encroachment had the least record of only $1.62 \%$ (table 3 ) is a clear evidence that there might have been high level of connivance between park officials and encroachers. This suspicion is confirmed by the fact that majority of the respondents perceive the host communities as poachers and aiders of encroachment (Table 4).

\subsection{Respondents' Perception about Encroachment}

Respondents are of the view that indigenes of host communities are involved in encroachment and aid encroachers from outside their communities (Table 4). Since the majority of the culprits were indigenes (table 4) it becomes difficult to apprehend them especially as they understood the terrain of the park environment more than the park officials. It will also be difficult for people living outside the host communities to successfully encroach into the park without assistance from members of host communities. Encroachment by indigenes is a sign of protest that they are not being favoured by park management even though CRNP has brought about some forms of development in the area. CRNP has built health centres, community center and bridges; renovated class rooms, employed natives, tarred roads from Butatong (park head quarter) to Okwango, once maintained Ikom Obudu highway and sometimes give communities opportunities to select the type of intervention that is their priority.

Respondents' high level of awareness concerning involvement of indigenes of host communities in encroachments is a pointer that many encroachers apprehended in the park were traced to the community. It also shows that the members of the community at different times may have attempted resisting arrest of some of their relations. It can also be ascribed to the fact that many arrested culprits were identified as indigenes of host communities. There were occasions where arrested poachers were released because the officials that caught the encroachers identified them as their community members (Gideon, per. Com.).

\subsection{Period of Intense Encroachment and Items Collected from CRNP}

Encroachment is experienced in the park at all season (Table 5). Wild animals and species like cattle stick are poached at all times. Irvingia fruits are harvested between May and September. Encroachment for fishing using poisonous chemicals is always experienced in enclave communities mostly during dry season. Poachers are attracted by resources in the park and most species (with exception of animals) have seasons of abundance in the park. These seasons of abundance differ on basis of species. A national park like Cross River National Park with high species diversity will therefore always have some species that are abundant at any period. In essence there are always resources at all times to attract poachers to CRNP. Though encroachment can be experienced at all season the abundance of more resources during rainy season attracts households (table 4). The fact that many respondents admitted that encroachment in the park can be experienced at all season is because there are vital floral non timber forest species that may not be needed by households during rainy season but only during drought period. In the case of Kainji Lake National Park intense encroachment is always experienced during dry season when the tall grasses therein would be dry and aid visibility.

Accessibility of many areas of CRNP constitutes a major challenge for both encroachers and park officials during the peak of rainy season. However, with good understanding of the terrain indigenes of the communities who are encroaching will have a better advantage to access the water logged areas than park officials. This is because they 
are already prepared to meet such situation. Besides, poachers trek on foot and some areas accessed with foot can hardly be reached with field vehicle. Similarly, Ijeomah and Ogbara (2013) reported of some ranges in Kainji Lake National Park, especially Wurumakoto, that are difficult to access by both park officials and poachers during rainy season. Animals, herbs and fish are the items mostly poached in CRNP (Table 5). This shows that the survival of households in park host communities depends heavily on animals, non timber forest products and fish. Similarly, the major items poached in Kainji Lake National Park include animals, fuelwood, herbs and fish (Ijeomah et al., 2012). In Pandam wildlife park animal, fish, thatch grass and fuelwood are the major items that attract encroachers (Ijeomah \& Emelue, 2009). In the case of Gashaka Gumti National Park primate species are hardly poached as most households in the bordering communities are dominantly Muslims and forbid consumption of primates (Eniang et al., 2011).

\section{Conclusion}

Hunting, collection of non timber forest products, fishing, farming and logging are among the major forms of encroachment in CRNP. When many NTFPs are put together the economic value could be more than that of timber. Collection of Cattlestick, Irvingia, Gnetum and many NTFPs is done at all season. The existing market for many NTFPs stimulates poachers to encroach into CRNP. Despite the quantity of Gnetum harvested it is not enough to serve the existing market. Tradesmen still harness from Gabon, Equitorial Guinea and Central African Republic. Gnetum is exported to USA, United Kingdom, France and other parts of the world where there are concentration of West Africans. This helps in aggravating the trend of harvesting the species. Hensia crenata is packaged, dried and exported to USA by air. The snail harvested from the park can hardly meet the market demand, poachers therefore travel to south west of Cameroon, from Younde to Douala where indigenes abhor consumption of the species for supplies. Encroachment for both wild animals and NTFPs is high. However, catching animal is a chance event and in many cases could generate noise while collection of NTFPs is a sure and noiseless event. The anti poaching activities of CRNP are not effective. Less emphasis is paid towards protection of NTFPs. The rate of arrests of culprits is low as the park protection staff are not always motivated. This is worsened by the fact that park officials especially employed indigenes of host communities, on many occasions connive with poachers.

CRNP has provided many forms of development among the park host communities and has employed some indigenes of these communities but the host communities are consistently making new demands and sometimes make impossible demands. When these demands are not met households use it as a basis to encroachment into the park. Non empowerment of households in host communities would finally lead to a build up of pressure that could lead to uncontrollable forms of encroachment and arsonic fires which will seriously threaten park resources.

The study is limited to qualitative information and record of arrest collected from the management of CRNP. Though record of arrest is an evidence of encroachment it does not give the exact rate of exploitation. With this method the actual number and quantity of species harnessed per operation and time cannot be known. Ecological survey should be conducted periodically in the park. This will give information on the diversity and abundance of species in the park per time. Comparing information on abundance and diversity of fauna and flora from different surveys gives a more quantitative insight on the level of threat of resources in the park. More game guards should be employed and members of park host communities have to be involved in the management cadre of the park.

\section{References}

Ajiwhen, I. O., \& Bisong, S. A. (2014). Effect of ethanolic extract of Carpolobia lutea G. Don (polygalaceae) root on learning and memory in CD1 mice. Nigerian Journal of Physiological Sciences, 28(2), 141-145.

Bero, J., Ganfon, H., Jonville, M., Frederick, M., Gbaguidi, F., Demol, P., \& Moudachirou, M. (2009). In-vitro evaluation of anti-plasmodial activity of plant samples used in traditional medicine in Benin. Journal of Ethnopharmacol, 122, 439-444. http://dx.doi.org/10.1016/j.jep.2009.02.004

Burkill, H. M. (1985): The useful plants of West tropical Africa (2nd ed., Vol 2). Royal Botanic Garden, Keaw, London.

Edet, D. I., \& Akinyemi, A. F. (2010). Importance of Wildlife and Non - Timber Forest Products of the Cross River Rainforest, Nigeria. In: H. M. Ijeomah, \& A. A. Aiyeloja, (Eds.), Practical Issues in Forest and Wildlife Resources Management (pp. 523 - 538). Green Canopy Consultants, Port Harcourt, Rivers State.

Emelue, G. U., \& Ijeomah, H. M. (2011). Incidence of Wildlife Offences and Wildlife Species Conservation in Yankari Wildlife Park, Nigeria. International Journal of Agricultural Economics and Extension Services, 1(1), 136 - 147. Nigeria.

Eniang, E. A., \& Ijeomah, H. M. (2011a). Diversity of Ophidian Species in Oban Division of the Cross River National Park, Nigeria. Production Agricultural Technology, 7(1), 188- 20. 
Eniang, E. A., \& Ijeomah, H. M. (2011b). Clandestine bushmeat trade in Cross River State, Nigeria: Implications on herp diversity and the environment. Global Approaches to Extension, 7(2), 1- 9. Nigeria.

Eniang, E. A., Ijeomah, H. M., Okeyoyin, G., \& Uwatt, A. E. (2011). Assessment Of Human - Wildlife Conflicts in Filinga Range of Gashaka Gumti National Park, Nigeria. Production Agriculture and Technology, 7(2), 15-35. Nigeria

Ettebong, E., \& Nwafor, P. (2009). In-vitro anti-microbial activities of extracts of Carpolobia lutea root. Pakistan Journal of Pharmaceutical Science, 22(3), 335-338.

Filkins, D. (2002). Terror in Africa: Attacks in Mombasa; Kenyans hunting clues to bombing, Toll rises to 13.The New York Times

Gettleman, J., \& Kulish, N. (2013). Gunmen Kill Dozens in Terror Attack at Kenyan Mall. The New York Times. Retrieved from September 21, 2013, from http://www.nytimes.com/2013/09/22/world/africa/nairobimall-shooting.html?pagewanted $=$ all\&_r $=0$

Idowu, P. A., Moody, J. O., \& Odelola, H. A. (2005). Phytochemical and anti-microbial screening of three Nigerian medicinal plants used to treat infectious diseases traditionally. Journal of Pharmacy and Bioresources, 2(2), 116-119.

Ijeomah, H. M., Alarape, A. A., \& Nwafor, O. E. (2005). Impact of Civil Crises on Wase Wildlife Park in Plateau State, Nigeria. Nigerian Journal of Agriculture, Food and Environment, 2(1), 35-41.

Ijeomah, H. M. (2007). Impact of Tourism on Perceived Poverty Alleviation in Plateau State, Nigeria. PhD Thesis, Department of Wildlife Management and Fisheries, University of Ibadan, 301pp.

Ijeomah, H. M., \& Emelue, G. U. (2009). Tourism Management and Sustainable Resource Utilization in Pandam Wildlife Park of Plateau State, Nigeria. Journal of Sustainable Development in Africa, 11(2), 206-222. Retrieved from http://www.jsd-africa.com

Ijeomah, H. M. (2012). Challenges of Game Reserves in Nigeria: A Case Study of Pai River Wildlife Park of Plateau State, Nigeria In H. M. Ijeomah, \& A. A. Aiyeloja (eds.), Challenges to Sustainable Production in Agriculture and the Environment: Nigeria in Perspective. Top Base Nigeria Limited, Lagos, in Conjunction with Green Canopy Consultants, Port Harcourt, Rivers State.

Ijeomah, H. M., \& Odunlami, S. S. (2013). The Politics of Wild Resources Management in Yankari Wildlife Park: Implications on Biodiversity Conservation and Ecotourism management. International Journal of Safety and Security in Tourism and Hospitality, 4, 36 -50.

Ijeomah, H. M., \& Ogbara, D. (2013). Challenges of Wildlife Management in Kainji Lake National Park, Nigeria. Nigerian Journal of Agriculture, Food and Environment, 9(1), 1- 8.

Ijeomah, H. M., Ogogo, A. U., \& Ogbara, D. (2013). Analysis of Poaching Activities in Kainji Lake National Park of Nigeria. Environment and Natural Resources Research, 3(1), 51-61. http://dx.doi.org/10.5539/ enrr.v3n1p51

Ijeomah, H. M., Eniang, E. A., \& Umuokoro, O. (2014). Coastal Tourism in Niger Delta Region of Nigeria (155-164). In O. Y. Ogunsanwo, A. O. Akinwole, I. O. Azeez, V. A. J. Adekunle, \& N. A. Adewole (Eds.), Sudano-Sahelian Landscape and Renewable Natural Resources Development in Nigeria, Proceedings of the $37^{\text {th }}$ Annual conference of the Forestry Association of Nigeria held in Minna, Niger State between $9^{\text {th }}$ and $14^{\text {th }}$ November, 2014.

Jackson, C., Mbagwu, H., Jackson, I., Ekpe, G., \& Etienam, F. (2011). Analgesic activities of ethanolic extract of the root of Carpolobia lutea. African Journal of Pharmacology, 5(3), 367-370. http://dx.doi.org/10.5897/ AJPP10.398

Misiko, H. (2014): How Kenya made itself vulnerable to terror. The Washinghton Post, June 17. Retrieved from http://www.washingtonpost.com/blogs/worldviews/wp/2014/06/17/how-kenya-made-itself-vulnerable-to-te rror/

Mitaine-offer, A., Miyamoto, T., Khan, I. A, Delaude, C., \& Dubois, M. (2002). Three new triterpenes saponins from two species of Carpolobia. Journal of natural products, 65, 533-557. http://dx.doi.org/10.1021 /np010546e

Nigerian Environmental Study Action / Team (NEST). (1991). Threatened Environment: A National Profile. Nigerian Environment Study/Action Team, Ibadan.288pp. 
Nwidu, L. L., \& Nwafor, P. A. (2009): Gastroprotective effects of leaf extracts of Carpolobia lutea (polygalaceae) G. Don in rats. African Journal of Biotechnology, 8(1), 012-019.

Nwidu, L. L., Nwafor, P. A., da Silva, V. C., Rodrigues, C. M., dos santos, L. C., Vilegas, W., \& Nunes-de souza, R. L. (2011). Anti-nociceptive effects of Carpolobia lutea G. Don (polygalaceae) leaf fractions in animal models. Inflammo pharmacol, 19(4), 215-225.

Okokon, J. E., Effiong, I. A., \& Etteobong, E. (2011). Invivo anti-malarial activities of ethanolic crude extracts and fractions of leaf and root of Carpolobia lutea. Pak. J. Pharm. Sci, 24(1), 57-61.

Onu, M. E., \& Ijeomah, H. M. (2010). Assessment of Bushmeat trade in Ikwerre Local Government Area of Rivers State: A case Study of Omagwa Bushmeat market. International Journal of Agriculture and Rural Development, 13(2), $281-286$.

Raman, B. (2002). Prairie fire of Terrorism spreads to Mombasa Paper No. 556, South Asia Analysis Group. Retrieved from http://www.southasiaanalysis.org/paper556

ThisDay in History. (1998). U.S. embassies in East Africa bombed. Retrieved from http://www.history.com/ this-day-in-history/us-embassies-in-east-africa-bombed

Udofia, S. I., Offiong, M. O., Ijeomah, H. M., \& Etefia, S. O. (2009). Non - Timber Forest Products in the Household Economy of Ini Local Government Area of Akwa Ibom State, Nigeria. Nigerian Journal of Agriculture, Food and Environment (Nigeria), 5(1), 52- 58.

\section{Copyrights}

Copyright for this article is retained by the author(s), with first publication rights granted to the journal.

This is an open-access article distributed under the terms and conditions of the Creative Commons Attribution license (http://creativecommons.org/licenses/by/3.0/). 